\title{
Vocabulary size, reading motivation, reading attitudes and reading comprehension performance among Filipino college learners of English
}

\author{
Rosalyn Gunobgunob-Mirasol \\ Department of English, University of Santo Tomas, Philippines
}

\begin{tabular}{l} 
Article Info \\
\hline Article history: \\
Received Aug 8, 2018 \\
Revised Oct 3, 2018 \\
Accepted Dec 6, 2018 \\
\hline Keywords: \\
Acquisition of competence \\
Reading attitude \\
Reading motivation \\
Reading comprehension \\
Vocabulary size
\end{tabular}

Article Info

Article history

Received Aug 8, 2018

Revised Oct 3, 2018

Accepted Dec 6, 2018

Vocabulary size

\begin{abstract}
Reading is an indispensable tool in the academic world. Most, if not all, activities in varied collegiate courses entail the act of reading. There are many contributing factors that affect one's ability to read and comprehend text materials effectively. Two of the many factors are the reader's vocabulary size and their reading motivation. This study examined the relationship of the vocabulary size, reading strategies and the reading comprehension performance of college learners in a comprehensive university in the Philippines. A correlational analysis was employed to ascertain the relationship between the scores in the reading comprehension component of the course and the vocabulary levels tests by Nation. The findings of this study hope to provide useful insights into the prediction of college learners' reading performance and the teaching of vocabulary in the ESL context as well as the integration of learners' reading motivation in the curriculum.
\end{abstract}

Copyright (C) 2019 Institute of Advanced Engineering and Science. All rights reserved.

\section{Corresponding Author:}

Rosalyn Gunobgunob-Mirasol, Department of English, Research Center for Social Sciences and Education, University of Santo Tomas, Espana Boulevard, Manila, Philippines. Email: rosalynmirasol@gmail.com

\section{INTRODUCTION}

A significant debate about second and even foreign language learners' poor reading ability and whether such inefficient reading ability should be ascribed to target language proficiency or reading problems took place in the mid-80's [1]. With today's millennial learners, there is also a great debate about the areas and the setting of the reading encounters of the students. As readers get exposed to varied reading encounters such as the use of online reading sites, the use of kindle, online books, and quick access to social media such as facebook, twitter, instagram, tinder, wattpad, ask.fm, and countless social media platforms brought about the new generation of readers today. With this shift from the print setting to digital setting, educators are challenged to determine what motivates the readers to read.

Reading instruction has five components which include phonemic awareness, phonics, word recognition, vocabulary, and comprehension. One cannot deny the fact that these five components are important. These components of reading instructions allow the students acquire necessary skills to be proficient readers. However, it is also important to consider the reader's will to read. According to Cambria and Guthrie [2], a good reader has both skill and will. This focuses on the motivation to read. They agree on the idea that motivation to read comes with readers' enjoyments, their wants, and their behaviours that envelope the act of reading. A reader may acquire important skills to make sense of the text, but without motivation, $\mathrm{s}$ /he cannot become a proficient and competent reader.

Reading attitude is defined as the "feeling about reading that results in the adoption or avoidance of positive reading habits" [3]. Another definition of reading attitude is "a system of feeling related to reading 
which causes the learner to approach or avoid a reading situation" [4]. The formation of a students' good reading attitude starts at home for it is where literacy awareness begins [5]-[7]. Home is also where reading motivation, or simply motivation, is fostered and enhanced. Motivation is a widely accepted key factor in language learning; it is the internal drive that pushes someone to achieve something [8]. Motivation is defined as "the personal goals, desires, and intentions of an individual [9]. When motivation is put into the context of reading, it is defined as "the individual's personal goals, values, and beliefs with regard to the topics, processes, and outcomes of reading" [9]. It is said that "motivation to read is a multidimensional concept which makes one's choice to come from varied reasons [10]. Some researchers believe that interest is classified as intrinsic motivation [2]. It means it is something that one does for his/her own sake [11]-[14] and reward is excluded in the idea. This implies that the reader values reading because he/she experiences highest level of connection with the text, himself/herself, and with the world. Reterlsdorf et al. [15] emphasized that reading enjoyment represents the activity-related component of intrinsic motivation. This inner motivation of the readers may lead to a better performance and competence in the school. Students who also have high intrinsic motivation are usually highly achieving readers [16]. Wigfield and Guthrie found that "students who are intrinsically motivated spend 300\% more time reading than students who have low intrinsic motivation for reading." Compared to ten other motivations, intrinsic motivation for reading was most highly associated with whether or not students read widely and frequently on their own accord [16]. Knoll [17] explored the relationship between motivation and reading comprehension in tenth grade English/language arts students and found a strong relationship between the two variables. This strong relationship seems to indicate that a focus upon the motivation of students with low reading scores would be beneficial to those individuals. Given this information that reading motivation of the learners seemed to decline as they approach higher learning and that reading motivation can be associated to the performance of the learners, it should be of important consideration that teachers look into the non-cognitive performance of the learners especially their reading attitudes and reading motivation.

This paper looked into the necessary and relevant details of our college readers today in terms of their vocabulary size, reading attitudes reading motivation and their relationship with their reading comprehension performance; thus, providing useful details into the prediction of college learners' reading performance and the teaching of vocabulary in the ESL context as well as the integration of learners' reading motivation in the curriculum. Specifically, this paper determined the following: (1) difference between male and female vocabulary size; (2) factors affecting vocabulary size; (3) relationships among the dimensions of motivation (4) relationship between reading attitude and motivation (5) dimensions of motivation that significantly affect the vocabulary size of the student; (6) reading attitudes of the respondents; (7) difference between students' reading attitudes towards academic and recreational purposes in print and digital environments; and (8) correlation between reading attitudes in purposes and settings.

\section{RESEARCH METHOD}

\subsection{Research design}

This paper employed quantitative - descriptive approach. This involves collections of quantitative information that can be tabulated along a continuum in numerical form, such as scores on a test or the number of times a person chooses to use a-certain feature of a multimedia program, or it can describe categories of information such as gender or patterns of interaction when using technology in a group situation [18]. Descriptive research involves gathering data that describe events and then organizes, tabulates, depicts, and describes the data collection [19].

\subsection{Subjects and study site}

A total of 121 college students were surveyed to determine their reading attitudes and reading motivation. They were also given a reading comprehension test before the semester ended. On one hand, the first generation of college students seem to be at a more or less high risk of being academically, socially, and economically left behind [20]. Because of their new environment, first year college may have higher anxiety over those who have stayed in college for more than a year. This scenario should move educators to look into their attitudes and motivation to better provide quality instruction to them. On the other hand, third year college has already determined characteristics as influenced by social, parental, and cognitive factors. As college students are given more academic loads such as homeworks, formative and summative assessments and the like, students spend more time reading materials that are already identified by their professors. It might be of interest to educators to determine whether interest-related reading is very low among third year students. This may be due to several factors such as individual, family, and social responsibilities [21].

Vocabulary size, reading motivation, reading attitudes and reading.... (Rosalyn Gunobgunob-Mirasol) 


\subsection{Instrumentation}

There were three instruments used in this study. The first one was the Adolescent Reading Attitudes Survey (ARAS) by Michael McKenna, the Motivation to Read by Wigfield, et al., and a reading comprehension text with the corresponding reading comprehension questions. The ARAS consists of 18 questions that ask the respondents of how they feel in situations that pertain to their purposes and setting in their reading activities. The Motivation to Read consists of 53 questions, of which 11 constructs were identified: reading efficacy, reading challenge, reading curiosity, reading involvement, importance of reading, reading work avoidance, competition in reading, recognition for reading, reading for grades, social reasons for reading, and compliance. Moreover, the students answered the vocabulary size test at my.vocabularysize.com to determine theyr vocabulary size. The respondents answered the reading comprehension questions were tested to find out the reliability using the Flesch-Kincaid Grade Level, with the result of 13.7 equivalent to college level text; and The SMOG Index, with the result of 13.2, which is also equivalent to a college level text.

\subsection{Data gathering procedure}

The researchers sought permission from selected students of first- and third-year college enrolled in the University of Santo Tomas. A letter of informed consent was given to them after explaining the objectives of the study. The survey was given on the second month of the second semester because during this stage, the students have already had the feeling of what it is to be a first-year college or a third-year college student. The first survey administered was the ARAS by Michael McKenna; a week after the ARAS, the researcher administered the motivation to read profile. The reading comprehension tests were administered on the second and fourth month of the semester. The results were then tabulated, and appropriate statistical tests were employed.

\section{RESULTS AND DISCUSSION}

Table 1 presents the significant difference between the students' gender and vocabulary size. Independent sample t-test and Levene's test for equality were used to determine the difference on the said variables, pretest scores, and post test scores. Results revealed that there is no significant difference in their vocabulary size $(\mathrm{t}(88)=-226, \mathrm{p}>.05)$, pretest scores $(\mathrm{t}(38)=1.135, \mathrm{p}>.05)$, and post test scores $(\mathrm{t}(38)=1.178$, $\mathrm{p}>.05)$ all considering equal variances.

Table 1. Significant difference in the vocabulary size and test scores of male and female students

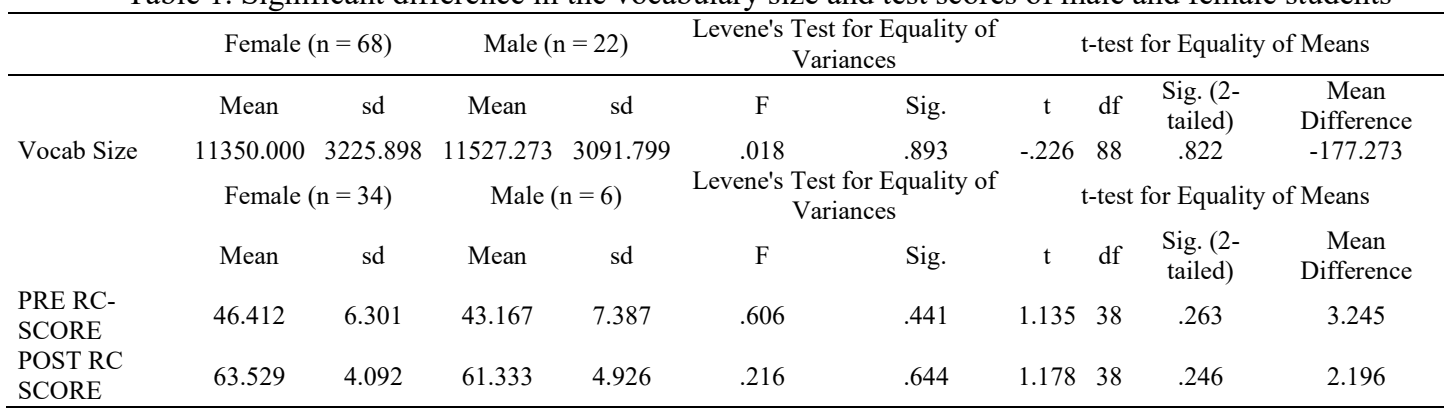

Table 2 presents which factos affect vocabulary size. Stepwise regression analysis is used to determine what factors affect the vocabulary size. Results revealed that reading attitude towards printed environment has significant positive effect to vocabulary size $\left(F(1,88)=4.003, p<.05, R^{2}=.044\right)$. However, the regression model indicates that only $4.4 \%$ of the variability in vocabulary size can be explained by the students' attitude towards printed environment.

Table 2. Regression analysis of reading attitude and vocabulary size

\begin{tabular}{lccccc}
\hline \multicolumn{5}{c}{ Unstandardized } \\
Coefficients & Standardized Coefficients & \\
Model & $\mathrm{B}$ & Std. Error & Beta & t & Sig. \\
\hline 1 (Constant) & 6884.779 & 2277.434 & & 3.023 & .003 \\
\multicolumn{1}{c}{ Print } & 989.173 & 494.413 & .209 & 2.001 & .049 \\
\hline Dependent Variable: Vocab Size $\left(\mathrm{F}(1,88)=4.003, \mathrm{p}=.049, \mathrm{R}^{2}=.044\right)$
\end{tabular}

Int. J. Eval. \& Res. Educ. Vol. 8, No. 1, March 2019: 64 - 70 
Table 3 presents the relationship among the dimensions of motivation. Pearson correlation coefficient is used to determine if there are significant relationships among the dimensions of motivation. Efficacy is significantly correlated with involvement $(\mathrm{r}=.189, \mathrm{p}<.05)$, importance $(\mathrm{r}=.387, \mathrm{p}<.01)$, competition $(\mathrm{r}=.430, \mathrm{p}<.01)$, and recognition $(\mathrm{r}=.476, \mathrm{p}<.01)$. Involvement is significantly correlated with importance $(r=.287, \mathrm{p}<.01)$ and recognition $(\mathrm{r}=.235, \mathrm{p}<.01)$. Significant correlation also exists between importance and competition $(\mathrm{r}=.378, \mathrm{p}<.01)$, importance and recognition $(\mathrm{r}=.486, \mathrm{p}<.01)$, and competition and recognition $(\mathrm{r}=.635, \mathrm{p}<.01)$. Among the dimensions of motivations, only involvement and competition are not significantly correlated $(\mathrm{r}=.147, \mathrm{p}>.05)$.

Table 3. Correlation among the dimensions of motivation $(n=121)$

\begin{tabular}{lrrrrr}
\hline \multicolumn{1}{c}{ Efficacy } & Involvement & Importance & Competition & Recognition \\
\hline Efficacy & 1 & \multicolumn{1}{c}{} \\
Involvement & $.189^{*}$ & 1 & & & \\
Importance & $.387^{* *}$ & $.282^{* *}$ & 1 & & \\
Competition & $.430^{* *}$ & .147 & $.378^{* *}$ & 1 & 1 \\
\multicolumn{1}{c}{ Recognition } & $.476^{* *}$ & $.235^{* *}$ & $.486^{* *}$ & $.635^{* *}$ & 1 \\
\hline **. Correlation is significant at the 0.01 level (2-tailed). & & &
\end{tabular}

*. Correlation is significant at the 0.05 level (2-tailed).

Table 4 presents the relationship between reading attitudes and motivation. Pearson correlation is used to determine if there is significant relationship between reading attitude and motivation. Reading attitude towards academic purposes and digital environment are not significantly correlated with the dimensions of motivations. However, reading attitude towards recreational purposes is significantly correlated with efficacy $(\mathrm{r}=.224, \mathrm{p}<.05)$, involvement $(\mathrm{r}=.451, \mathrm{p}<.01)$, importance $(\mathrm{r}=.256, \mathrm{p}<.01)$, competition $(\mathrm{r}=.197, \mathrm{p}<.05)$, and recognition $(\mathrm{r}=.324, \mathrm{p}<.01)$. Additionally, reading attitude towards printed environment is significantly correlated with efficacy $(r=.261, p<.05)$, involvement $(r=.418, p<$ $.01)$, importance $(\mathrm{r}=.304, \mathrm{p}<.01)$, and recognition $(\mathrm{r}=.247, \mathrm{p}<.01)$.

Table 4. Correlation between dimensions of motivation and reading attitudes

\begin{tabular}{lcccc}
\hline & Academic & Recreational & Print & Digital \\
\hline Efficacy & .108 & $.224^{*}$ & $.261^{* *}$ & .012 \\
Involvement & .135 & $.451^{* *}$ & $.418^{* *}$ & .062 \\
Importance & .102 & $.256^{* *}$ & $.304^{* *}$ & -.020 \\
Competition & .067 & $.197^{*}$ & .145 & .086 \\
Recognition & .031 & $.324^{* *}$ & $.247^{* *}$ & .035 \\
\hline **. Correlation is significant at the 0.01 level (2-tailed). \\
*. Correlation is significant at the 0.05 level (2-tailed).
\end{tabular}

Table 5 presents which dimension of motivation affects the vocabulary size of the students. Stepwise regression analysis is used to determine what dimensions of motivation significantly affect the vocabulary size of the student. Results revealed that only efficacy has significant positive effect on vocabulary size $\left(\mathrm{F}(1,88)=5.207, \mathrm{p}<.05, \mathrm{R}^{2}=0.56\right)$. The positive effect of efficacy indicates that higher level of efficacy leads to bigger vocabulary size. However, the regression model shows that only $5.6 \%$ of the variability in vocabulary size can be explained by efficacy.

Table 5. Regression analysis between motivation and vocabulary size.

\begin{tabular}{|c|c|c|c|c|c|c|}
\hline \multirow{2}{*}{\multicolumn{2}{|c|}{ Model }} & \multicolumn{5}{|c|}{ Unstandardized Coefficients Standardized Coefficients } \\
\hline & & $\mathrm{B}$ & Std. Error & Beta & $\mathrm{t}$ & Sig. \\
\hline \multirow[t]{2}{*}{1} & (Constant) & 7531.185 & 1723.879 & & 4.369 & .000 \\
\hline & Efficacy & 1420.681 & 622.592 & .236 & 2.282 & .025 \\
\hline
\end{tabular}

Table 6 presents the general description of the reading attitudes of the students. It can be noted that the top three items that have garnered the most positive attitudes from the respondents fell under the Recreational purpose; and the bottom three fell under the academic purpose. In general, though, the students have positive reading attitude $(\mathrm{M}=4.560, \mathrm{sd}=.352)$. 
Table 6. Descriptive statistics of the reading attitudes of the students

\begin{tabular}{|c|c|c|c|c|c|}
\hline \multicolumn{6}{|c|}{ Top three result } \\
\hline Item No. & Statement & Purpose & Setting & Mean & $\mathrm{Sd}$ \\
\hline 15 & $\begin{array}{l}\text { How do you feel about being on social media like Facebook or Twitter } \\
\text { in your free time? }\end{array}$ & Recreational & Digital & 5.111 & 1.040 \\
\hline 10 & How do you feel about texting friends in your free time? & Recreational & Digital & 4.966 & .937 \\
\hline 8 & $\begin{array}{l}\text { How do you feel about talking with friends about something you've } \\
\text { been reading in your free time? }\end{array}$ & Recreational & Print & 4.923 & 1.018 \\
\hline \multicolumn{6}{|c|}{ Bottom three result } \\
\hline 12 & $\begin{array}{l}\text { How do you feel about working on an internet project with } \\
\text { classmates? }\end{array}$ & Academic & Digital & 4.197 & 1.131 \\
\hline 7 & How do you feel about reading a book online for a class? & Academic & Digital & 4.009 & 1.063 \\
\hline 3 & $\begin{array}{l}\text { How do you feel about doing a research using encyclopedias (or other } \\
\text { books) for a class? }\end{array}$ & Academic & Print & 3.923 & 1.035 \\
\hline
\end{tabular}

Table 7 presents students' reading attitudes towards academic and recreational purposes in print and digital environments. It can be noted that the top three items that have garnered the most positive attitudes from the respondents fell under the Recreational purpose; and the bottom three fell under the academic purpose. In general, the students have positive reading attitude $(\mathrm{M}=4.560, \mathrm{sd}=.352)$. The students have significantly higher level of reading attitude for recreational purposes $(\mathrm{M}=4.830, \mathrm{sd}=.643)$ as compared to academic $(\mathrm{M}=4.315, \mathrm{sd}=.634),(\mathrm{t}(120)=9.518, \mathrm{p}<.001)$. However, considering the environment, students' level of attitude towards printed materials $(\mathrm{M}=4.528, \mathrm{sd}=.682)$ and digital materials $(\mathrm{M}=4.564$, $\mathrm{sd}=.664)$ are not significantly different $(\mathrm{t}(120)=.547, \mathrm{p}>.05)$.

Table 7. Significant difference between students' reading attitudes towards academic and recreational purposes in print and digital environments

\begin{tabular}{|c|c|c|c|c|c|c|c|c|c|c|c|}
\hline & & \multicolumn{9}{|c|}{ Paired Differences } & \multirow{3}{*}{$\begin{array}{l}\text { Sig. (2- } \\
\text { tailed) }\end{array}$} \\
\hline & & \multirow[t]{2}{*}{ Mean } & \multirow[t]{2}{*}{$\mathrm{sd}$} & \multirow[t]{2}{*}{$\begin{array}{c}\text { Mean } \\
\text { difference }\end{array}$} & \multirow[t]{2}{*}{$\begin{array}{c}\text { sd of } \\
\text { difference }\end{array}$} & \multirow[t]{2}{*}{$\begin{array}{l}\text { Std. } \\
\text { Error } \\
\text { Mean }\end{array}$} & \multicolumn{2}{|c|}{$\begin{array}{l}95 \% \text { Confidence } \\
\text { Interval of the } \\
\text { Difference }\end{array}$} & \multirow[t]{2}{*}{$\mathrm{t}$} & \multirow[t]{2}{*}{ df } & \\
\hline & & & & & & & Lower & Upper & & & \\
\hline \multirow{2}{*}{ Purpose } & Academic & 4.315 & .634 & -.515 & .595 & .054 & -.622 & -.408 & -9.518 & 120 & .000 \\
\hline & Recreational & 4.830 & .643 & & & & & & & & \\
\hline \multirow[t]{2}{*}{ Environment } & Print & 4.528 & .682 & -.037 & .740 & .067 & -.170 & .096 & -.547 & 120 & .585 \\
\hline & Digital & 4.564 & .664 & & & & & & & & \\
\hline
\end{tabular}

Table 8 presents the correlation between reading attitudes in purposes and settings. It was found out that there was a significant positive correlation between and among the students reading attitudes towards purposes and environment. Significant correlations exist between students' attitude towards academic and recreational purposes $(\mathrm{r}=.567, \mathrm{p}<0.01)$, attitude towards printed and digital materials $(\mathrm{r}=.396, \mathrm{p}<.01)$. These indicate that those students with higher level of reading attitude towards academic purposes are also those with higher level of reading attitude toward recreational purposes which is true also for the attitude of the students toward printed and digital environment. Significant correlations also exist between students' attitude towards academic purposes and printed materials $(\mathrm{r}=.756, \mathrm{p}<0.1)$; academic purposes and digital materials $(\mathrm{r}=.803, \mathrm{p}<.01)$; recreational purposes and printed materials $(\mathrm{r}=.769, \mathrm{p}<.01)$; and recreational purposes and digital materials $(\mathrm{r}=.612, \mathrm{p}<.01)$.

Table 8 . Correlation between students' reading attitude towards in purposes and settings

\begin{tabular}{|c|c|c|c|c|}
\hline & Academic & Recreational & Print & Digital \\
\hline Academic & 1 & & & \\
\hline Recreational & $.565^{* *}$ & 1 & & \\
\hline Print & $.756^{* *}$ & $.803^{* * *}$ & 1 & \\
\hline Digital & $.769^{* *}$ & $.612^{* *}$ & $.396^{* *}$ & 1 \\
\hline
\end{tabular}

\section{CONCLUSION}

This paper investigated the role of reading attitudes and reading motivation to the respondents' vocabulary size and reading comprehension performance. Generally, the respondents have positive attitudes in reading in both settings and purpose and that respondents who have higher level of reading attitude 
towards academic purposes are also those with higher level of reading attitude toward recreational purposes which is true also for the attitude of the students toward printed and digital environment.

Motivation, specifically the construct on reading efficacy, may seem to affect their vocabulary size. This result suggests that it is important to increase the motivation of the students to read as the amount of reading may lead to an increase in vocabulary size.

Although students seem to have positive attitudes in reading digitally, exposure to print environment is still deemed important as studies revealed that students learn better in reading using printed texts. Purpose in reading matters; therefore, readers must know their purpose in reading. A conscious awareness of why students read needs to be considered in the teaching and learning environment.

In the digital world, many thinks that printed texts may seem less important over digital texts; however, looking at the results of comprehension tests, one cannot underestimate the power of printed texts. Exposure to both settings is highly important then so that students can have an equal chance of looking at where they perform better.

\section{ACKNOWLEDGEMENTS}

The researchers would like to express their gratitude to the Research Center for Social Sciences and Education of the University of Santo Tomas, Manila, Philippines

\section{REFERENCES}

[1] Al-Nujaidi A.H., "The relationship between vocabulary size, reading strategies, and reading comprehension of efl learners in saudi Arabia," 2000, Retrieved from https://shareok.org/ bitstream/handle/ 11244/44607/ Thesis-2003DA452r.pdf? sequence =1\&isAllowed=y on April 5, 2017.

[2] Cambria, J. and Guthrie, J., "Motivating and engaging students to reading," The New England Reading Association Journal, vol. 46(1), pp. 16-29, 2010. Retrieved from http://www.literacyconnects.org/img/2013/03/Motivating-andengaging-students-in-reading-Cambria-Guthrie.pdf on April 5, 2017.

[3] Hagan E., "Student Reading Attitudes in Relation to the Instructional Approach," 2013. Retrieved from http://www.nwmissouri.edu/library/researchpapers/2013/Hagan\%20,\%20Elizabeth.pdf on May 3, 2017.

[4] Alexander J. and Filler, R., "Attitudes and reading," Newark, DE: International Reading Association, 1976.

[5] Cook V., "The influences of home and family on the development of literacy in children," School Psychology Review, vol. 9, pp. 369-373, 1980.

[6] Morrow C., "Developing young voluntary readers: the home-the child-the school," Reading Research and Instruction, vol. 25, pp. 1-8, 1985.

[7] Gove A. and Cvelich P. "Early reading: Igniting education for all, a report by the early grade learning community of practice," 2010. Retrieved October 8, 2017, from http://www.uis.unesco.org: http://www.uis.unesco.org/Education/Documents/early-reading-report-gove_cvelich.pdf

[8] Senturk B., "EFL Turkish University Students' Attitudes and Motivation Towards Reading in English," Procedia Social and Behavioral Sciences, vol. 199, pp. 704-712, 2015. doi:10.1016/j.sbspro.2015.07.601

[9] Guthrie J. and Wigfield, A., "Engagement and motivation in reading," (R. Barr, M. Kamil, P. Mosenthal, \& P. Pearson, Eds.) New York: Longman Publishing, 2000.

[10] Mante-Estacio J., "Dimensions of Reading Motivation among Filipino Bilinguals," TESOL Journal, vol. 7, pp.10-26, 2012.

[11] DePasque S. \& Tricomi E., "Effects of intrinsic motivation on feedback processing during learning," NeuroImage, vol. 119, pp. 175-186, 2015.

[12] Wang J. H. Y. and Guthrie J. T. "Modeling the effects of intrinsic motivation, extrinsic motivation, amount of reading, and past reading achievement on text comprehension between U.S. and Chinese students," Reading Research Quarterly, vol. 39, pp. 162-186, 2004.

[13] Wigfield A. and Guthrie J. T., "Relations of children's motivation for reading to the amount and breadth or their reading," Journal of Educational Psychology, vol. 89(3), pp. 420-432, 1997.

[14] Neugebauer S. "A daily diary study of reading motivation inside and outside of school: a dynamic approach to motivation to read," Learning and Individual Differences, vol. 24, pp. 152-159, 2013.

[15] Retelsdorf J., Köller O., Möller, J. "On the effects of motivation on reading performance growth in secondary school," Learning and Instruction, vol. 21, pp. 550-559, 2011.

[16] McRae A., and Guthrie, J.T. "Promoting reasons for reading: Teacher practices that impact motivation," In E. H. Hiebert (Ed.), Reading more, reading better , New York: Guilford Press, pp. 55-76, 2009.

[17] Knoll C., "The relationship between motivation and reading," 2000. Retrieved from https://pdfs.semanticscholar.org/ad83/abf940e65ecd49fdcabee60d6dc52a486d1e.pdf on May 5, 2017

[18] "What is descriptive research?," Educational Communications and Technology, 2001. Retrieved January 16, 2018 from http://members.aect.org/edtech/ed1/41/41-01.html

[19] Glass G. V. and Hopkins K. D., "Statistical Methods in Education and Psychology (2nd ed.)," Englewood Cliffs, N. J.: Prentice-Hall, 1984.

[20] Pascarella E. T., Pierson C. T., Wolniak G. C., and Terenzini, P. T. "First-generation college students: Additional evidence on college experiences and outcomes," Journal of Higher Education, vol.75(3), pp. 249-284, 2004.

Vocabulary size, reading motivation, reading attitudes and reading.... (Rosalyn Gunobgunob-Mirasol) 
[21] Tandom M., "How do we re-arouse adults' students interest in reading?," Research on leisure reading habits, 2012, Retrieved August 3, 2016 from https://goo.gl/A5gRqH.

\section{BIOGRAPHY OF AUTHOR}

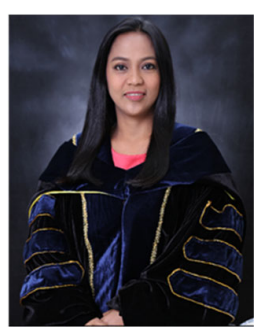

Rosalyn G. Mirasol, Ph.D. is an associate professor at the Department of English, University of Santo Tomas, and Manila, Philippines. She is also a research associate at the Research Center for Social Sciences and Education in the same University. Dr. Mirasol is a Board of Director of the Reading Association of the Philippines and an active member of International Literacy Association. Her research interests include reading attitudes, cognitive and noncognitive assessments of reading proficiency, and she advocates home school reading collaborations. 